\title{
Celebrating 40 years since DSM-III
}

\author{
Fred R. Volkmar ${ }^{1} \mathbb{D}$
}

Accepted: 28 August 2021 / Published online: 7 October 2021

(C) The Author(s), under exclusive licence to Springer Science+Business Media, LLC, part of Springer Nature 2021

\begin{abstract}
This special section celebrates the first official recognition of Autism as a diagnostic concept in 1980 in the third edition of the American Psychiatric Association's Diagnostic and Statistical Manual. The articles in this special section note the many areas of significant progress made as well as areas that remain important topics for continued and future research. The official recognition of autism as a diagnostic concept has significantly advanced both clinical work and research.
\end{abstract}

Keywords Autism · DSM-III · Diagnosis

Just over 40 years have now passed since the landmark 3rd edition of the American Psychiatric Association Diagnostic and Statistical Manual-DSM-III (American Psychiatric Association, 1980). Before DSM-III appeared, there was no official recognition of autism and both clinical work and research suffered as a result (American Psychiatric Association, 1980); In the first article in this section Rosen and colleagues (Rosen et al., 2021) summarize that the rational for autism's official recognition rested on several important and distinctive lines of evidence and despite some problems with the definition it significantly advanced work in the area. As Rosen and colleagues discuss important issues and areas of diagnostic controversy remain even in the face of attempts to produce better revised definitions of the condition. These controversies have to do with issues like gender and cultural issues, the complexities of Asperger's disorder, and the broader autism phenotype even while the most recent name change to Autism Spectrum Disorder has been well received. In the next article Fombonne and colleagues (Fombonne et al., 2021) note the important advances and challenges that have come with official recognition and epidemiological research. As they emphasize, challenges include culturally based work and continued surveillance studies of autism but compared to what we knew back in 1980 knowledge has advanced markedly. The quality of outcome studies began to increase in both number and sophistication. As Howlin

Fred R. Volkmar

Fred.volkmar@yale.edu

1 Yale University Child Study Center, PO Box 207900, New Haven, CT 06520, USA reviews (Howlin, 2021), the evolving ways in which autism has been conceptualized have had significant importance in planning for adult services and evaluating changes in outcome. Similarly, as Vivanti and Messinger discuss (Vivanti \& Messinger, 2021) the official diagnosis of the condition has led to a number of important attempts to develop psychological models and theories of autism that can both guide research and may also have important implications for clinical work. The growing consensus on best approaches to diagnosis of autism has also significantly advanced work in the area of genetics; this work, first begun in the 1970's, has now emerged as one of the major areas of research interest in the condition and, as Thapar and Rutter discuss (Thapar $\&$ Rutter 2020), there have been important implications for understanding the heritability of autism and its diagnostic boundaries. Similarly work on the neuroscience of autism has been significantly advanced as we now understand much more about some important basic aspects of brain functioning in ASD and have seen autism emerge as, in many ways, the prototypic disorder for the study of the social brain (McPartland et al., 2021).

Advances in interventions for ASD have similarly been facilitated by the initial recognition of autism. This has been particularly noteworthy in the area of behavioral interventions (Odom et al., 2021) which have become more sophisticated and are now frequently the basis of treatment. Similarly, advances have occurred in the area of psychopharmacology (Henneberry et al., 2021). The growing literature on interventions (Leaf et al., 2020) has also led to a new body of work that evaluates treatments more rigorously and makes recommendations regarding whether interventions 
can be regarded as evidence based. In their important review Odom and colleagues note the major areas of advance in this area as well as the important gaps in translation of research into clinical practice in school and home settings. Finally, the recognition of autism as a diagnostic concept has raised important issues of social policy for local, state, national, and international planning (Doehring, 2021). In the final article in this series of papers, Doehring discusses the important challenges in the areas of science, ethics, and social policy. While much has been accomplished much remains to be done.

I thank all the authors who have contributed to this special section of the Journal and commend their work to readers as it gives us all a chance to 'step back' and reflect on where we have come from and where we are going in the many different aspects of the field.

\section{Declarations}

Conflict of interest The author receives book royalties from Springer, Wiley, Guilford, Wolter's Kluwer, and Cambridge University Press. $\mathrm{He}$ is on the board of Chapel Haven, Inc. New Haven, CT and the professional advisory board of Kyocera, Inc. He serves as Editor of this Journal.

Research Involving Human Participants No issues of human subject consent apply to this article.

\section{References}

American Psychiatric Association. (1980). Diagnositc and statistical manual (3rd ed.). USA: APA Press.

Doehring, P. (2021). Does the arc of science bend towards impact? Four decades of empirical research published in JADD since the DSM-III. Journal of Autism and Developmental Disorders. https://doi.org/10.1007/s10803-021-05052-2
Fombonne, E., MacFarlane, H., \& Salem, A. C. (2021). Epidemiological surveys of ASD: Advances and remaining challenges. Journal of Autism and Developmental Disorders. https://doi.org/10.1007/ s10803-021-05005-9

Henneberry, E., Lamy, M., Dominick, K., \& Erickson, C. A. (2021). Decades of progress in the psychopharmacology of autism spectrum disorder. Journal of Autism snd Developmenal Disorders, In Press

Howlin, P. (2021). Adults with autism: Changes in understanding since DSM-111. Journal of Autism and Developmental Disorders. https://doi.org/10.1007/s10803-020-04847-z

Leaf, J. B., Cihon, J. H., Ferguson, J. L., Milne, C. M., Leaf, R., \& McEachin, J. (2020). Advances in our understanding of behavioral intervention: 1980 to 2020 for individuals diagnosed with autism spectrum disorder. Journal of Autism and Developmental Disorders. https://doi.org/10.1007/s10803-020-04481-9

McPartland, J. C., Lerner, M. D., Bhat, A., Clarkson, T., Jack, A., Koohsari, S., Matuskey, D., McQuaid, G. A., Su, W. C., \& Trevisan, D. A. (2021). Looking back at the next 40 years of ASD neuroscience research. Journal of Autism and Developmental Disorders. https://doi.org/10.1007/s10803-021-05095-5

Odom, S. L., Hall, L. J., Morin, K. L., Kraemer, B. R., Hume, K. A., McIntyre, N. S., Nowell, S. W., Steinbrenner, J. R., Tomaszewski, B., Sam, A. M., \& DaWalt, L. (2021). Educational interventions for children and youth with autism: A 40-year perspective. Journal of Autism and Developmental Disorders. https://doi.org/10. 1007/s10803-021-04990-1

Rosen, N. E., Lord, C., \& Volkmar, F. R. (2021). The diagnosis of autism: From Kanner to DSM-III to DSM-5 and beyond. Journal of Autism and Developmental Disorders. https://doi.org/10.1007/ s10803-021-04904-1

Thapar, A., \& Rutter, M. (2020). Genetic advances in autism. Journal of Autism and Developmental Disorders. https://doi.org/10.1007/ s10803-020-04685-z

Vivanti, G., \& Messinger, D. S. (2021). Theories of autism and autism treatment from the DSM III through the present and beyond: Impact on research and practice. Journal of Autism and Developmental Disorders. https://doi.org/10.1007/s10803-021-04887-z

Publisher's Note Springer Nature remains neutral with regard to jurisdictional claims in published maps and institutional affiliations. 